\title{
International Accounting Stand- ards en de gevolgen voor de jaarverslaggeving in Nederland
}

Prof. Dr. R.G.A. Vergoossen

\section{Inleiding}

De International Accounting Standards (IASs), opgesteld door het International Accounting Standards Committee (IASC), zullen in de nabije toekomst onmiskenbaar gevolgen hebben voor de Nederlandse verslaggevingspraktijk. Op indirecte wijze doordat de Raad voor de Jaarverslaggeving (RJ) IASs incorporeert in zijn Richtlijnen voor de jaarverslaggeving, en voor beursgenoteerde ondernemingen mogelijk ook op een meer directe wijze, bijvoorbeeld wanneer de Amsterdam Exchanges (AEX) of de Stichting Toezicht Effectenverkeer (STE) - al dan niet in navolging van de International Organization of Securities Commissions (IOSCO) - besluiten de toepassing van IASs voor te schrijven'. Bovendien is het niet uitgesloten dat de wetgever besluit om de vennootschappelijke en de geconsolideerde jaarrekening te ontkoppelen en beursgenoteerde ondernemingen toe te staan of zelfs te verplichten de geconsolideerde jaarrekening in overeenstemming met IASs op te stellen. De Nederlandse wetgever zou hiertoe zelfstandig kunnen besluiten in navolging van bijvoorbeeld Duitsland en Frankrijk, maar kan er te zijner tijd ook toe worden gedwongen als gevolg van eisen die de Europese Commissie in de toekomst aan de jaarverslaggeving van beursgenoteerde ondernemingen mogelijk gaat stellen.

Prof. Dr. R.G.A. Vergoossen RA is hoogleraar Internationale Externe Berichtgeving aan de Universiteit Maastricht en lid van de directie van het Koninklijk NIVRA. Hij maakt deel uit van de Nederlandse delegatie in de Board van het International Accounting Standards Committee
In dit artikel worden de gevolgen voor de Nederlandse verslaggevingspraktijk besproken aan de hand van een analyse van belangrijke of opvallende verschillen die er op dit moment bestaan tussen IASs en de Nederlandse verslaggevingsregels $^{2}$. De gevolgen worden in voorkomende gevallen geillustreerd met praktijkvoorbeelden ${ }^{3}$.

De verschillen tussen de IASC-regelgeving en de regelgeving in Nederland kunnen in drie categorieën worden ingedeeld ${ }^{4}$ :

1 IASC-regelgeving die in strijd is met Nederlandse wettelijke bepalingen;

2 IASC-regelgeving die bestaande opties in de Nederlandse wet- en regelgeving inperkt;

3 IASC-regelgeving die vergeleken met de Nederlandse wet- en regelgeving om aanzien-

lijk meer informatie in de toelichting vraagt.

Uitgangspunt bij de verschillenanalyse is de IASC-regelgeving zoals vastgelegd in de bundel International Accounting Standards 1999 (IASC, 1999) en de Nederlandse wet- en regelgeving opgenomen in de bundel Richtlijnen voor de jaarverslaggeving (jaareditie 1998).

\section{Strijdigheid met wettelijke bepalingen}

Strijdigheden tussen IASC-regelgeving en de Nederlandse wet manifesteren zich onder meer op de volgende terreinen:

immateriële vaste activa;

- negatieve goodwill;

- waardeverminderingen; afschrijving onroerend goed;

- waardering deelnemingen;

- financiële instrumenten;

- consolidatie-uitsluitingen. 


\subsection{Immateriële vaste activa}

Zelfontwikkelde immateriële vaste activa dienen volgens IAS 38 onder bepaalde voorwaarden te worden geactiveerd en - bij voorkeur - te worden gewaardeerd tegen kostprijs onder aftrek van afschrijvingen en waardeverminderingen. Als alternatief kan ook tegen reële waarde worden gewaardeerd. IAS 38 is in strijd met artikel 2:385.4 en 2:384. 1 BW, want volgens deze wetsbepalingen mogen alleen van derden anders dan om niet verkregen immateriële vaste activa in de balans worden opgenomen die alleen mogen worden gewaardeerd tegen de verkrijgings- of vervaardigingsprijs.

Het is de vraag of toepassing van IAS 38 op dit punt zal leiden tot grote aanpassingen in de jaarverslaggeving van Nederlandse ondernemingen. In IAS 38 wordt immers expliciet aangegeven dat zelfontwikkelde merken, uitgaverechten, klantenbestanden en dergelijke niet in de balans mogen worden opgenomen. Bovendien worden aan het activeren van zelfontwikkelde immateriële vaste activa die niet tot deze groep behoren zeer strikte voorwaarden gesteld. Daarbij wordt een onderscheid gemaakt tussen de onderzoeksfase en de ontwikkelingsfase van projecten. Kosten gemaakt in de onderzoeksfase mogen in het geheel niet worden geactiveerd, terwijl kosten gemaakt in de ontwikkelingsfase aan bepaalde eisen moeten voldoen alvorens die in de balans mogen worden opgenomen (IAS 38.39-55).

De afschrijvingstermijn kan overigens nog een bottleneck vormen in de toepassing van IAS 38 door Nederlandse ondernemingen. Kosten van onderzoek en ontwikkeling moeten namelijk volgens de Nederlandse wet worden afgeschreven in een periode van maximaal vijf jaar (artikel 2:386.3 BW), terwijl de afschrijvingstermijn in IAS 38 niet is gelimiteerd.

\section{Voorbeeld 1: VNU}

VNU activeert niet alleen gekochte maar ook zelfontwikkelde uitgaverechten. De aan uitgaverechten toe te kennen waarde is gerelateerd aan hun winstgevendheid, met als maximum de gemaakte kosten. Als uitgaverechten niet slijten door het gebruik of het verloop van de tijd worden zij niet stelselmatig afgeschreven, maar wordt de waarde jaarlijks getoetst. Als daarbij een duurzame waardevermindering van een uitgaverecht wordt vastgesteld, wordt de geactiveerde waarde verlaagd door een bijzondere afschrijving ten laste van de winst- en verliesrekening (jaarverslag VNU, 1997, p. 41).

De verwerkingswijze van zelfontwikkelde uitgaverechten is niet in overeenstemming met de letter van de wet. De beschouwing van de RJ inzake een aantal aspecten van de behandeling van immateriële vaste activa biedt wel aanknopingspunten (RJ 210, bijlage alinea 15). Aangezien IAS 38 het activeren van zelfontwikkelde uitgaverechten expliciet verbiedt, zal toepassing van deze standaard bij VNU ertoe leiden dat de zelfontwikkelde uitgaverechten van de balans verdwijnen en zal het eigen vermogen dienovereenkomstig dalen. Ook de winstcijfers worden hoogstwaarschijnlijk beïnvloed. De richting een stijging of daling - is evenwel afhankelijk van de verhouding tussen de afschrijvingen c.q. duurzame waardeverminderingen enerzijds en de gemaakte kosten anderzijds.

\subsection{Negatieve goodwill}

Negatieve goodwill dient volgens IAS 22 in de balans te worden gepresenteerd als aftrekpost van de geactiveerde (positieve) goodwill. Deze presentatiewijze is strijdig met artikel 2:389.8 BW dat voorschrijft dat negatieve goodwill moet worden verantwoord als herwaarderingsreserve voorzover die geen nadelen weerspiegelt die voor de onderneming aan de deelneming zijn verbonden (lucky buy). In geval van een 'lucky buy' heeft toepassing van IAS 22 door Nederlandse ondernemingen een positief effect op het gepresenteerde eigen vermogen. De invloed op het gepresenteerde nettoresultaat is afhankelijk van het tempo waarin de herwaarderingsreserve vrijvalt en de wijze waarop die vrijval wordt verantwoord: ten gunste van de overige reserves of via de winst- en verliesrekening.

\subsection{Waardeverminderingen}

In Nederland kennen we een duurzaamheidscriterium bij waardeverminderingen van vaste activa, dat wil zeggen dat waardeverminderingen in aanmerking worden genomen indien die naar verwachting duurzaam zijn (artikel 2:387.4 BW). In IAS 36 ontbreekt een duurzaamheidscriterium, 
hetgeen betekent dat waardeverminderingen direct in aanmerking worden genomen. In beide gevallen wordt een afboeking ongedaan gemaakt zodra de waardevermindering heeft opgehouden te bestaan. Het zal duidelijk zijn dat toepassing van IAS 36 door het ontbreken van het duurzaamheidscriterium bij Nederlandse ondernemingen zou kunnen leiden tot grotere fluctuaties in de gepresenteerde winstcijfers.

\subsection{Afschrijvingen onroerend goed}

Afschrijvingen van beleggingen in onroerend goed mogen volgens IAS 25 achterwege blijven. Dit is in strijd met artikel 2:386.4 BW dat bepaalt dat op vaste activa met beperkte levensduur jaarlijks wordt afgeschreven volgens een stelsel dat op de verwachte toekomstige gebruiksduur is afgestemd. Deze strijdigheid geldt overigens niet voor financiële instellingen, zoals verzekeringsmaatschappijen en beleggingsinstellingen, die artikel 2:386.4 niet behoeven toe te passen. Het gebruikmaken van de mogelijkheid die IAS 25 biedt, zal in voorkomende gevallen leiden tot hogere winstcijfers en een hoger eigen vermogen.

\subsection{Waardering deelnemingen}

Dochtermaatschappijen en deelnemingen waarop invloed van betekenis wordt uitgeoefend moeten op grond van IAS 27 respectievelijk 28 in de enkelvoudige jaarrekening van de deelnemende rechtspersoon worden gewaardeerd tegen verkrijgingsprijs of volgens de zogenaamde equity-methode. Laatstgenoemde methode wil zeggen dat op het moment van verwerving de dochtermaatschappij of deelneming wordt gewaardeerd tegen verkrijgingsprijs waarop in latere jaren vermogensmutaties plaatsvinden. IAS 27 en 28 zijn in beginsel strijdig met artikel 2:389 BW. Volgens deze wettelijke bepaling namelijk moeten dochtermaatschappijen en deelnemingen waarop invloed van betekenis wordt uitgeoefend in de enkelvoudige jaarrekening van de deelnemende rechtspersoon in principe worden opgenomen tegen de nettovermogenswaarde. De nettovermogenswaarde van een dochtermaatschappij of deelneming is de waarde op basis van de waarderings- en resultaatbepalingsgrondslagen van de deelnemende rechtspersoon. Dit betekent dat het nettoresultaat en het eigen vermogen in de enkelvoudige jaarrekening van de deelnemende rechtspersoon en de geconsolideerde jaarrekening aan elkaar gelijk zijn.

Toepassing van IASC-regelgeving zal er dus toe leiden dat de enkelvoudige en geconsolideerde jaarrekening van elkaar gaan afwijken voor wat betreft het nettoresultaat en het eigen vermogen.

Voorbeeld 2: Unilever $N V$

Unilever NV neemt in de enkelvoudige jaarrekening de aandelen in groepsmaatschappijen op tegen kostprijs, omdat dit in overeenstemming is met internationaal gebruik. Dit leidt ertoe dat de nettowinst en het eigen vermogen in de enkelvoudige jaarrekening van de moedermaatschappij afwijken van de nettowinst en het eigen vermogen in de geconsolideerde jaarrekening. In de enkelvoudige jaarrekening 1997 van Unilever NV bedraagt de nettowinst $f 3.010$ miljoen en het eigen vermogen $f 6.700$ miljoen. In de geconsolideerde jaarrekening 1997 daarentegen bedraagt de nettowinst $f 7.662$ miljoen en het eigen vermogen $f 16.098$ miljoen.

Dit soort verschillen zijn ongewoon in de jaarrekening van Nederlandse ondernemingen. Door de toepassing van IASC-regelgeving zou dit evenwel een normaal beeld worden.

\subsection{Financiële instrumenten}

Financiële instrumenten die onder de vlottende activa worden opgenomen, dienen volgens IAS 39 in principe te worden gewaardeerd tegen reële waarde. Dit is strijdig met artikel 2:384.1 BW, waaruit blijkt dat dit soort activa moet worden gewaardeerd tegen verkrijgingsprijs of lagere marktwaarde. De RJ stelt overigens dat beursgenoteerde effecten tegen marktwaarde moeten worden gewaardeerd, indien dat voor het wettelijk vereiste inzicht noodzakelijk is ( $R J$ 226.107).

Ongerealiseerde waardestijgingen van financiële instrumenten met een handelsdoel (financial instruments held for trading) moeten volgens IAS 39 onmiddellijk in de winst- en verliesrekening worden verwerkt. Deze verwerkingswijze is bovendien een optie met betrekking tot financiële instrumenten zonder een handelsdoel (financial instruments available-for-sale). Het onmiddellijk in de winst- en verliesrekening verantwoorden van ongerealiseerde waardestijgingen is in strijd met 
artikel 2:384.2 BW. In het verlengde van RJ 226.107 bepaalt de RJ echter dat ongerealiseerde waardestijgingen van beursgenoteerde effecten wel onmiddellijk in de winst- en verliesrekening moeten worden verantwoord indien dat voor het wettelijk vereiste inzicht noodzakelijk is (RJ 226.110).

Toepassing van IAS 39 op de hiervoor besproken punten is aldus in strijd met de wet doch niet noodzakelijkerwijs met de Richtlijnen voor de jaarverslaggeving. Het is evident dat de toepassing van IAS 39 vergeleken met de toepassing van de Nederlandse wettelijke bepalingen ter zake zal leiden tot grotere fluctuaties in de gepresenteerde resultaten.

\subsection{Consolidatie-uitsluitingen}

IAS 27 verbiedt expliciet het buiten de consolidatie houden van dochtermaatschappijen met sterk afwijkende bedrijfsactiviteiten. Dit verbod is strijdig met artikel 2:406.3 BW. Hierin wordt namelijk bepaald dat groepsmaatschappijen met sterk afwijkende bedrijfsactiviteiten buiten de consolidatie moeten worden gehouden, indien dat strijdig zou zijn met het door de geconsolideerde jaarrekening krachtens artikel 2:362.1 BW te verschaffen inzicht ${ }^{5}$.

Aangezien zelden een beroep wordt gedaan op onderhavige uitsluitingsclausule, zal toepassing van IAS 27 op dit punt nauwelijks invloed hebben op de Nederlandse verslaggevingspraktijk.

\section{Inperking bestaande opties}

Toepassing van IASs beperkt het aantal opties dat de Nederlandse wet- en regelgeving op verschillende terreinen biedt. Het betreft opties met betrekking tot het (moment van) opnemen van posten in de balans, de waardering en resultaatbepaling en de presentatie of classificatie van posten. Belangrijke inperkingen doen zich onder meer voor met betrekking tot:

- immateriële vaste activa;

- deelnemingen;

- voorzieningen;

- pensioenen;

- financiële instrumenten;

- buitengewone baten en lasten.

\subsection{Immateriële vaste activa}

Waarschijnlijk de meest in het oog springende en inmiddels hevig bediscussieerde inperking heeft betrekking op de verwerkingswijze van betaalde goodwill. Betaalde goodwill moet volgens IAS 22 worden geactiveerd en vervolgens afgeschreven. De Nederlandse wet daarentegen staat ook toe dat betaalde goodwill in één keer rechtstreeks ten laste van het eigen vermogen wordt gebracht. Nederlandse ondernemingen maken doorgaans van deze optie gebruik. De voordelen voor een onderneming om betaalde goodwill rechtstreeks ten laste van het eigen vermogen te brengen zijn evident: de winstcijfers in een bepaald jaar worden niet aangetast door de in dat jaar en/of voorgaande jaren betaalde goodwill en de rentabiliteitscijfers worden positief beïnvloed. Daartegenover staat als nadeel de negatieve invloed op de solvabiliteitscijfers doordat de betaalde goodwill in één keer ten laste van het eigen vermogen wordt gebracht. De effecten van de aanpassing aan IAS 22 met betrekking tot de verwerking van betaalde goodwill zullen met name bij de multinationale ondernemingen groot zijn als gevolg van de hoge goodwillbedragen die in het recente verleden zijn betaald ${ }^{6}$.

Overigens gaan de laatste jaren steeds meer multinationale ondernemingen over op het activeren en vervolgens afschrijven van betaalde goodwill. De grondslagwijziging wordt evenwel niet met terugwerkende kracht doorgevoerd, dat wil zeggen het nieuwe stelsel - activeren en afschrijven - is uitsluitend van toepassing op 'nieuwe goodwill'. Hierdoor wordt voorkomen dat eerder betaalde goodwill, die rechtstreeks ten laste van het eigen vermogen is gebracht, alsnog een drukkend effect heeft op toekomstige winstcijfers.

\section{Voorbeeld 3: Arcadis}

Arcadis brengt betaalde goodwill in één keer rechtstreeks ten laste van het eigen vermogen. In het Form 20-F van Arcadis over 1997 staan ook cijfers wanneer de betaalde goodwill zou zijn geactiveerd en afgeschreven over een geschatte gebruiksduur variërend tussen 10 en 25 jaar. US GAAP schrijven deze verwerkingswijze voor. In 1997 leidt toepassing van US GAAP door Arcadis tot een daling van de nettowinst met $13 \%$ ( $f$ 5,7 miljoen) en een stijging van het eigen vermogen met 59\% ( $f$ 98,5 miljoen).

Toepassing van IAS 22 zou voor Arcadis waarschijnlijk dezelfde gevolgen hebben gehad. 
IAS 38 schrijft voor dat alle immateriële vaste activa in de balans moeten worden opgenomen indien aan de activeringscriteria - waarschijnlijkheid toekomstig economisch voordeel en betrouwbaarheid waardering - wordt voldaan. In paragraaf 2 hebben we al gezien dat immateriële vaste activa volgens de Nederlandse wet alleen mogen worden geactiveerd indien zij van derden anders dan om niet zijn verkregen, uitgezonderd de kosten gemaakt in verband met onderzoek en ontwikkeling. De Nederlandse wetgever geeft verder aan dat het uit een oogpunt van voorzichtigheid vaak de voorkeur verdient om ook verworven immateriële vaste activa niet te activeren (zie RJ 210, bijlage alinea 14).

Immateriële vaste activa moeten op grond van IAS 38 altijd op systematische wijze worden afgeschreven. De economische gebruiksduur van immateriële vaste activa is volgens het IASC altijd eindig. De Nederlandse wet daarentegen biedt ruimte om niet systematisch af te schrijven indien er sprake is van een oneindige gebruiksduur. Het zal duidelijk zijn dat wanneer Nederlandse ondernemingen immateriële vaste activa in de balans opnemen waarop in principe niet wordt afgeschreven, toepassing van IAS 38 doorgaans zal leiden tot lagere winstcijfers en een lager eigen vermogen.

\section{Voorbeeld 4: PolyGram}

PolyGram schrijft immateriële vaste activa anders dan goodwill alleen af indien en voorzover de indirecte opbrengstwaarde lager is dan de boekwaarde. In het Form 20-F geeft PolyGram ook cijfers wanneer deze activa systematisch zouden worden afgeschreven. US GAAP schrijven dit immers voor. PolyGram hanteert in dat kader voor muziekcatalogi en de catalogi van filmrechten, muziekauteursrechten en theaterproductierechten een lineair afschrijvingssysteem met afschrijvingstermijnen van 15 tot 25 jaar. In het Form 20-F van PolyGram over 1997 (pp. F-24/ 25) komt naar voren dat toepassing van US GAAP leidt tot een daling van de nettowinst over 1997 met 14\% ( $f 114$ miljoen) en van het eigen vermogen ultimo 1997 met $18 \%$ ( $f 739$ miljoen).

Aangezien ook IAS 38 systematische afschrijving voorschrijft, zou toepassing van deze standaard ongeveer dezelfde effecten op de gepresenteerde cijfers hebben gehad.

\subsection{Deelnemingen}

IAS 21 schrijft voor dat direct in het eigen vermogen verantwoorde valuta-omrekeningsverschillen met betrekking tot een buitenlandse deelneming alsnog in de winst- en verliesrekening worden opgenomen bij afstoting van die deelneming. De Nederlandse wet- en regelgeving bevat een dergelijke bepaling niet. Toepassing van de IASC-regelgeving op dit punt kan leiden tot grotere fluctuaties in de gepresenteerde resultaten.

Voorbeeld 5: Océ-van der Grinten

US GAAP schrijft voor dat bij de verkoop van buitenlandse deelnemingen de valutaomrekeningsverschillen die in voorgaande jaren direct in het eigen vermogen zijn verwerkt, alsnog in de winst- en verliesrekening worden verantwoord. In het Form 20-F van Océ-van der Grinten over het boekjaar 1987/1988 (p. F27) heeft dit geleid tot een aanpassing, omdat de verwerkingswijze in de volgens Nederlandse grondslagen opgestelde jaarrekening 1987/1988 onder meer op onderhavig punt afwijkt. Deze aanpassing leidt tot een daling van de nettowinst over $1987 / 1988$ met $36 \%$ ( $f 27$ miljoen).

Toepassing van IAS 21 zou eenzelfde invloed op de gepresenteerde winstcijfers hebben gehad.

\subsection{Voorzieningen ${ }^{7}$}

Voor het opnemen van voorzieningen gelden volgens IAS 37 stringente criteria. In Nederland is het toegestaan dat er voorzieningen voor reorganisaties en herstructureringen worden getroffen op grond van een besluit van de ondernemingsleiding, en bestaan er geen specifieke eisen ten aanzien van de aard van de posten die in dergelijke voorzieningen mogen worden opgenomen. Het IASC daarentegen geeft voorschriften met betrekking tot het tijdstip van het treffen van reorganisatie- en herstructureringsvoorzieningen en het karakter van de verplichtingen en kosten die in dergelijke voorzieningen moeten worden opgenomen (IAS 37.70-83). Voorzieningen voor reorganisaties en herstructureringen mogen pas worden getroffen wanneer er een gedetailleerd plan bestaat en de uitvoering van het plan al in gang is gezet of aan betrokkenen is bekendgemaakt. 
In Nederland is het mogelijk om een egalisatievoorziening in de balans op te nemen, bijvoorbeeld met betrekking tot de kosten van groot onderhoud. IAS 37 biedt deze mogelijkheid echter niet.

Toepassing van IAS 37 door Nederlandse ondernemingen betekent dat de mogelijkheden tot het voeren van een voorzieningenbeleid gericht op winstegalisatie aanmerkelijk worden ingeperkt ${ }^{8}$. De gepresenteerde resultaten kunnen hierdoor meer gaan fluctueren.

\section{Voorbeeld 6: Philips}

Philips heeft in de jaarrekening 1995 herstructureringskosten verwerkt ad $f 302$ miljoen, waarvan $f 40$ miljoen met betrekking tot de afwaardering van activa. Aangezien het personeel pas in 1996 van de herstructurering in kennis is gesteld, mochten volgens US GAAP de kosten ad $f 262$ miljoen pas in de jaarrekening 1996 worden verantwoord. In het Form 20-F van Philips over 1996 (p. 89) valt af te lezen dat aanpassing aan US GAAP heeft geleid tot een stijging van de nettowinst over 1995 met 10\% ( $f 262$ miljoen) en een stijging van het nettoverlies over 1996 met 44\% ( $f 262$ miljoen).

Toepassing van IAS 37 zou soortgelijke consequenties voor de gepresenteerde cijfers hebben gehad.

In Nederland is het toegestaan om bij de bepaling van de nettovermogenswaarde op het moment van verwerving van een deelneming rekening te houden met toekomstige kosten van reorganisatie en herstructurering. Wanneer de betaalde goodwill rechtstreeks ten laste van het eigen vermogen wordt gebracht, worden deze reorganisatie- en herstructureringskosten buiten de winst- en verliesrekening gehouden. Zoals eerder besproken staat IAS 22 het rechtstreeks ten laste van het eigen vermogen brengen van betaalde goodwill niet toe. Bovendien stelt IAS 22 aan de vorming van een reorganisatieen herstructureringsvoorziening bij de bepaling van de nettovermogenswaarde stringente voorwaarden (IAS 22.26-31). Deze voorwaarden zijn afgeleid uit IAS 37 inzake voorzieningen.

\section{Voorbeeld 7: Ahold}

Ahold heeft in 1996 de Amerikaanse supermarktketen Stop \& Shop verworven. Bij de bepaling van de betaalde goodwill is rekening gehouden met kosten in verband met de reorganisatie van Aholds activiteiten in de Verenigde Staten. US GAAP staat dit echter niet toe. In het Form 20-F van Ahold over 1996 (p. 73) valt te lezen dat aanpassing aan US GAAP op dit punt heeft geleid tot een daling van de nettowinst met $13 \%$ ( $f 81$ miljoen). Het betreft de in dat jaar gemaakte reorganisatiekosten.

Toepassing van IAS 22 zou waarschijnlijk soortgelijke consequenties hebben gehad, aangezien deze standaard in grote lijnen overeenstemt met US GAAP.

Voorzieningen moeten volgens IAS 37 worden gewaardeerd tegen contante waarde wanneer die materieel afwijkt van de nominale waarde. In Nederland daarentegen is de norm dat voorzieningen tegen nominale waarde worden gewaardeerd. Belastingvoorzieningen echter moeten volgens IAS 12.53 altijd tegen nominale waarde worden gewaardeerd, terwijl die in Nederland ook tegen contante waarde kunnen worden gewaardeerd.

\section{Voorbeeld 8: $A B N A M R O$}

$A B N$ AMRO waardeert de voorziening voor belastingverplichtingen tegen contante waarde, terwijl volgens US GAAP waardering tegen nominale waarde moet plaatsvinden. Dit laatste is in overeenstemming met IAS 12. In het Form 20-F van ABN AMRO over 1997 (pp. F-39 en F-44) kan echter worden afgelezen dat de effecten van de toepassing van US GAAP op de nettowinst en het eigen vermogen van te verwaarlozen betekenis is.

\subsection{Pensioenen}

IAS 19 bevat gedetailleerde voorschriften met betrekking tot de berekening van de pensioenkosten en pensioenvoorziening. In de Nederlandse verslaggevingspraktijk toegepaste berekeningswijzen voor de pensioenvoorziening en pensioenkosten wijken op een aantal punten af van de in IAS 19 voorgeschreven berekeningswijze. Zo wordt in Nederland bij de berekeningen doorgaans uitgegaan van de huidige salarissen, terwijl volgens het IASC rekening moet worden gehouden met toekomstige salarisontwikkelingen. Ook 
is er een verschil met betrekking tot de disconteringsvoet. In Nederland is een (lage) vaste rekenrente gebruikelijk. terwijl op grond van IAS 19 moet worden gerekend met een van de marktrente afgeleid percentage. Dit laatste zal tot een lagere pensioenvoorziening leiden. Het effect wordt evenwel gemitigeerd doordat volgens IAS 19) rekening moet worden gehouden met toekomstige salarisontw ikkelingen.

\section{Voorbeeld 9: KLM}

KLM kwantificeert in het Form 20-F de invloed op de nettowinst en het eigen vermogen van de toepassing van de Amerikaanse standaard inzake pensioenen (Statement of Financial Accounting Standards No. 87; SFAS 87). In het boekjaar 1996/97 leidt dit tot een stijging van de nettowinst met $164 \%$ ( $f 387$ miljoen) en van het eigen vermogen met $44 \%$ ( $f 1.492$ miljoen).

Aangezien IAS 19 grote gelijkenis heeft met SFAS 87, zou toepassing van IAS 19 waarschijnlijk ongeveer dezelfde gevolgen hebben gehad.

\subsection{Finunciële instrumenten}

Financiële instrumenten dienen volgens IAS 39 al op het moment van contractafsluiting te worden opgenomen in de balans. Volgens RJ 130.113 worden rechten en verplichtingen voortvloeiende uit eenzelfde overeenkomst niet in de balans opgenomen indien en voorzover noch de onderneming noch de tegenpartij op de balansdatum heeft gepresteerd. Toepassing van IAS 39 door Nederlandse ondernemingen betekent aldus dat financiële instrumenten eerder op de balans verschijnen.

\subsection{Buitengerione baten en lasten}

IAS 8 stelt stringente voorwaarden aan de verantwoording van buitengewone baten en lasten. Alleen zeldzame gebeurtenissen. zoals onteigeningen en natuurrampen. kunnen aanleiding geven tot het opnemen van buitengewone posten in de winst- en verliesrekening. In Nederland wordt een ruimere definitie voor buitengewone baten en lasten gehanteerd. Boekwinsten en -verliezen bij de afstoting van deehnemingen en dotaties aan reorganisatie- en herstructureringsvoorzieningen. bijvoorbeeld, kunnen als buiten- gewoon worden aangemerkt. Toepassing van de strengere $\mathrm{I} \Lambda \mathrm{SC}$-regelgeving betekent voor Nederlandse ondernemingen dat zij minder mogelijkheden hebben het resultaat uit gewone bedrijlsuitoefening te egaliseren.

De voorbeelden van buitengewone posten die in IAS 8 worden gegeven (onteigeningen en natuurrampen), kunnen in Nederland overigens ook buiten de winst- en verliesrekening om als rechtstreekse mutaties in het eigen vermogen worden verwerkt.

\section{Uitbreiding informatic in toelichting}

Toepassing van IASs leidt tot een aanzienlijke uitbreiding van de informatie die in de toelichting moet worden verstrekt. Dit manifesteert zich onder meer op de volgende terreinen:

- immateriële vaste activa;

overnames;

- leasing;

- pensioenen;

bijzondere waardeverminderingen;

- beëindiging van bedrijfsactiviteiten;

- tussentijdse berichten.

Hierna worden de verschillen slechts in grote lijnen geschetst. VNO-NCW (1998) geeft een uitgebreide analyse van de verschillen tussen IASs en de Nederlandse wet- en regelgeving op genoemde terreinen.

\section{I Immateriële vaste activa}

Vergeleken met de Nederlandse wet- en regelgeving zijn de eisen die IASs stellen ten aanzien van de informatieverstrekking in de toelichting omtrent goodwill (IAS 22) en immateriële vaste activa (IAS 38) veel uitgebreider en gedetailleerder. Voor een deel zijn die additionele toelichtingsvereisten een logisch uitvloeisel van de verschillen in de verslaggevingsgrondslagen.

\subsection{Overnames}

IAS 22 schrijft voor dat de kosten van een overname moeten worden vermeld. Daarnaast moet een beschrijving worden gegeven van de wijze waarop de aankoopprijs is betaald of van de voorwaarden waaronder betaling nog zal plaatsvinden. Indien de reële waarden van de activa en passiva of de aankoopprijs nog niet met zekerheid 
zijn vast te stellen, dient dit feit met de redenen hiervoor te worden vermeld.

\subsection{Leasing}

De eisen die IAS 17 stelt aan de informatieverschaffing in de toelichting omtrent financiële en operationele lease-overeenkomsten gaan veel verder dan de Richtlijnen voor de jaarverslaggeving. Dit geldt voor de jaarrekening van zowel de lessee als de lessor.

\subsection{Pensioenen}

De presentatie- en toelichtingsvoorschriften opgenomen in IAS 19 omtrent pensioenverplichtingen en pensioenkosten zijn uitgebreider en gedetailleerder dan de Richtlijnen voor de jaarverslaggeving op dit terrein.

\subsection{Bijzondere waardeverminderingen}

IAS 36 schrijft voor dat bijzondere waardeverminderingen of terugnemingen daarvan in de jaarrekening worden vermeld, uitgesplitst naar soort activa. Bij belangrijke afwaarderingen of terugnemingen daarvan dient onder meer informatie te worden verstrekt over de omvang, de oorzaken en de berekeningswijze.

\subsection{Beëindiging van bedrijfsactiviteiten}

De Richtlijnen voor de jaarverslaggeving bevatten nauwelijks presentatie- en toelichtingsvoorschriften met betrekking tot de beëindiging van bedrijfsactiviteiten. IAS 35 daarentegen bepaalt dat per af te stoten activiteit uitgebreide informatie moet worden verstrekt.

\subsection{Tussentijdse berichten}

De eisen die IAS 34 stelt aan de inhoud van tussentijdse berichten gaan veel verder dan de bepalingen dienaangaande in de Richtlijnen voor de jaarverslaggeving. Zo dient een tussentijds bericht volgens IAS 34 minimaal een gecomprimeerde balans, winst- en verliesrekening, kasstroomoverzicht, mutatie-overzicht eigen vermogen en een toelichting te bevatten. In Nederland moet in een tussentijds bericht ten minste de netto-omzet en het resultaat vóór of na belastingen worden vermeld.

\section{Evaluatie}

In dit artikel is nagegaan wat de gevolgen van de toepassing van IASs zullen zijn voor de jaarverslaggeving in Nederland. In de inleiding is al aangegeven dat de invloed van IASs op de Nederlandse verslaggevingspraktijk zich op directe en indirecte wijze kan manifesteren.

De directe invloed van IASs is vrij beperkt. Integrale toepassing van IASs is in Nederland zeldzaam. De auteur is maar één Nederlandse onderneming bekend, namelijk Gucci Group NV, die in het financiële jaarverslag expliciet meldt dat de jaarrekening in overeenstemming met IASs is opgesteld (annual report Gucci Group NV, 1997, p. 54).

Hoewel veel stelselwijzigingen - met name in de jaarrekening van multinationale ondernemingen - zijn doorgevoerd vanwege internationale ontwikkelingen wordt slechts sporadisch expliciet verwezen naar IASs. Bij de stelselkeuze speelt een beursnotering in de Verenigde Staten overigens een belangrijke rol ${ }^{9}$. Toepassing van US GAAP zal vaak toepassing van IASs impliceren, aangezien beide regelgevingen voor een groot deel met elkaar overeenstemmen.

De invloed van IASs op de Nederlandse verslaggevingspraktijk manifesteert zich op dit moment vooral op een indirecte wijze, dat wil zeggen door de toepassing van (ontwerp-)Richtlijnen waarin IASs zijn verwerkt. Belangrijke IASs, zoals die met betrekking tot immateriële vaste activa, voorzieningen en financiële instrumenten, moeten nog in de Richtlijnen voor de jaarverslaggeving worden verwerkt.

Het zal duidelijk zijn dat de effecten van een integrale toepassing van IASs op de gepresenteerde cijfers en de informatie in de toelichting zeer groot kunnen zijn en zowel gelijktijdig als volgtijdig sterk kunnen verschillen. Gelijktijdige verschillen zijn de verschillen tussen ondernemingen in een bepaalde periode, met volgtijdige verschillen wordt gedoeld op de verschillen in opeenvolgende perioden bij een bepaalde onderneming ${ }^{10}$. De gevolgen van de toepassing van IASs - gelijktijdig en volgtijdig - zullen immers sterk afhangen van de verslaggevingsgrondslagen waarvoor is gekozen, van de (resterende) afwijkingen van IASs en van de omvang van de posten waarop de afwijkingen betrekking hebben. Daarbij is het - wat de (resterende) afwijkingen 
betreft - van belang permanente en niet-permanente afwijkingen te onderscheiden. Door permanente afwijkingen wordt de hoogte van de gepresenteerde resultaten op systematische wijze beïnvloed. namelijk wanneer kosten of opbrengsten volgens een bepaalde methode in de winsten verliesrekening worden verwerkt, terwijl die volgens een andere methode buiten de winst- en verliesrekening om, rechtstreeks ten laste respectievelijk ten gunste van het eigen vermogen worden gebracht. Bij niet-permanente afwijkingen daarentegen is er van een systematische beïnvloeding geen sprake, maar treden er in de tijd verschuivingen in de hoogte van de gepresenteerde resultaten op doordat kosten of opbrengsten volgens een bepaalde methode eerder of later in de winst- en verliesrekening worden verantwoord dan volgens een andere methode" ${ }^{\prime \prime}$

Door het globale karakter en de daaruit voortvloeiende flexibiliteit van de Nederlandse wet- en regelgeving is het, op enkele uitzonderingen na. mogelijk om verslaggevingsgrondslagen te kiezen die overeenstemmen met IASs. Dit betekent dat er nauwelijks afwijkingen behoeven te zijn. Bij de ene onderneming kan een bepaalde afwijking van IASs de gepresenteerde cijfers evenwel substantieel beïnvloeden, terwijl diezelfde afwijking bij de andere onderneming geen of nauwelijks invloed heeft. Bovendien kan het zo zijn dat de effecten van bepaalde afwijkingen op de gepresenteerde cijfers elkaar voor een belangrijk deel compenseren.

Op basis van de analyse in dit artikel kunnen we stellen dat toepassing van IASs door Nederlandse ondernemingen vaak zal leiden tot:

- een lager resultaat;

- een hoger eigen vermogen;

minder rechtstreekse mutaties in het eigen vermogen;

- minder buitengewone baten en lasten; grotere fluctuaties in het patroon van het nettoresultaat en het resultaat uit gewone bedrijfsuitoefening;

- minder wijzigingen in de grondslagen van waardering en resultaatbepaling;

meer informatie in de toelichling.

Toepassing van IASs zal bij veel Nederlandse ondernemingen leiden tot lagere winstcijfers en een hoger eigen vermogen. Dit wordt vooral veroorzaakt doordat de bij acquisities betaalde goodw ill volgens IASs moet worden geactiveerd en vervolgens afgeschreven, terwijl de meeste Nederlandse ondernemingen de betaalde goodwill nog steeds in één keer rechtstreeks ten laste van het eigen vermogen brengen.

ln de tijd gezien zal toepassing van IASs leiden tot grotere fluctuaties in de gepresenteerde resultaten. Dit geldt zowel voor het nettoresultaat als voor het resultaat uit gewone bedrijfsuitoefening. Vooral de strengere criteria die in IASs gelden voor het opnemen van voorzieningen, de zeer beperkte mogelijkheden van rechtstreekse mutaties in het eigen vermogen en het opnemen van buitengewone posten in de winst- en verliesrekening zijn hier debet aan.

Toepassing van IASs perkt het aantal opties in die de Nederlandse wet- en regelgeving kent. Dit betekent dat er voor Nederlandse ondernemingen minder keuzemogelijkheden blijven bestaan, hetgeen impliceert dat het aantal wijzigingen in de grondslagen van waardering en resultaatbepaling zal afnemen.

Doordat IASs vergeleken met de huidige Nederlandse wet- en regelgeving om meer en gedetailleerder informatie vraagt, zal toepassing van IASs leiden tot een aanzienlijke uitbreiding van de informatieverstrekking in de toelichting.

Ter illustratie van de invloed van verschillende regelgevingen op de gepresenteerde winstcij-

Figutr 1: Netrowinst AEGON 1984-1998

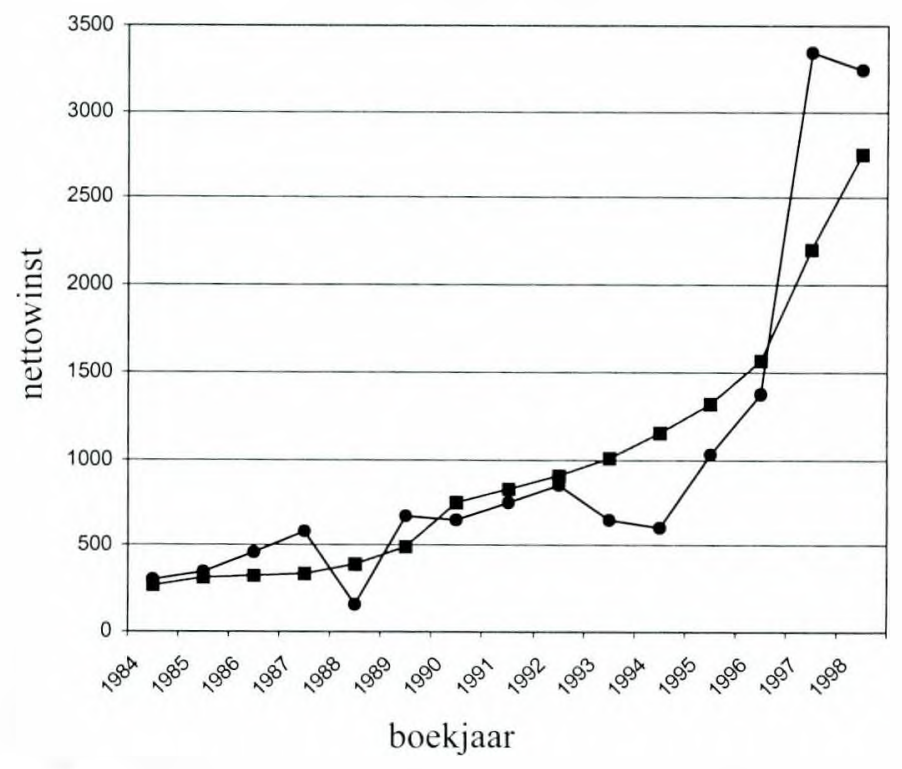

nettowinst volgens Nederlandse wet- en regelgeving nettowinst volgens US GAAP 
fers is in figuur 1 het verloop van de nettowinst in de jaren 1984 tot en met 1998 van AEGON volgens US GAAP en volgens de Nederlandse wet- en regelgeving opgenomen.

\section{I T E R A T U U R}

Amsterdam Exchanges, (1999), Primaire markt consultatienota, Amsterdam.

Arnold, C.A. en H.N.M. van der Voorn, (1995), Rapportering volgens de IASC-standaards, Maandblad voor Accountancy en Bedriifseconomie, april.

Contactcomité Jaarrekeningenrichtlijnen, (1996), Een onderzoek naar de conformiteit tussen de internationale standaarden voor jaarrekeningen en de Europese jaarrekeningenrichtlijnen, Brussel.

Europese Commissie, (1999), Examination of the conformity between International Accounting Standards and the European Accounting Directives, Brussel.

Fédération des Experts Comptables Européens, (1999), Comparison of the EC Accounting Directives and IASs: A contribution to international accounting developments, Brussel.

Hoogendoorn, M.N., J.A.G.M. Koevoets en R.G.A. Vergoossen (red.), (1996), Het jaar vers/agen: Onderzoek jaarverslaggeving 1995, Kluwer Bedrijfswetenschappen/Koninklijk NIVRA, Deventer.

International Accounting Standards Committee, (1999), International Accounting Standards 1999, Londen.

Koevoets, J.A.G.M., L.G. van der Tas en R.G.A. Vergoossen (red ). (1997). Het jaar 1996 verslagen: Onderzoek jaarverslaggeving Nederlandse ondernemingen, Kluwer BedrijfsInformatie/Koninklijk NIVRA, Deventer.

Koevoets, J.A.G.M., L.G. van der Tas en R.G.A. Vergoossen (red.), (1998), Het jaar 1997 verslagen: Onderzoek jaarverslaggeving Nederlandse ondernemingen, Kluwer/Koninklijk NIVRA, Deventer

Raad voor de Jaarverslaggeving, (1998), Richtlijnen voor de jaarverslaggeving (jaareditie 1998), Kluwer, Deventer.

Overboom, C.P.M. en R.G.A. Vergoossen, (1997), Voorzieningen en jaarrekeningbeleid, Maandblad voor Accountancy en Bedriffseconomie, september.

Tas, L.G. van der, Financiële vers/aggeving: verantwoording en verantwoordelijkheid van het management in internationaal perspectief, Erasmus Universiteit, Rotterdam.

Vereniging VNO-NCW, (1998), Internationale verslaggevingsregels in Nederland toepasbaar?: analyse en enquête, Den Haag.

Vergoossen, R.G.A., (1996), Invloed beursnotering in Verenigde Staten op stelselkeuze en additionele informatieverschaffing, Maandblad voor Accountancy en Bedriffseconomie, november.
Vergoossen, R.G.A. en A.A.R. Polman, (1995), US GAAP en de jaarverslaggeving van Nederlandse ondernemingen, Maandblad voor Accountancy en Bedriffseconomie, september.

\section{NOT E N}

1 Zie AEX (1999, pp. 41/42) waarin AEX een duidelijke voorkeur uitspreekt voor IASs.

2 Voor een meer gedetailleerde verschillenanalyse wordt verwezen naar VNO-NCW (1998). Ook in de jaarverslaggevingsonderzoeken die de afgelopen drie jaar onder auspiciën van het Koninklijk NIVRA zijn uitgevoerd, wordt uitgebreid ingegaan op verschillen tussen de IASC-regelgeving en de Nederlandse wet- en regelgeving (Hoogendoorn, Koevoets en Vergoossen, 1996; Koevoets, Van der Tas en Vergoossen, 1997; Koevoets, Van der Tas en Vergoossen, 1998). Voor studies op Europees niveau naar de mate waarin de Europese jaarrekeningenrichtlijnen overeenstemmen met IASs wordt verwezen naar Contactcomité Jaarrekeningenrichtlijnen (1996), Europese Commissie (1999) en Fédération des Experts Compta. bles Européens (1999).

3 De praktijkvoorbeelden zijn met name ontleend aan de zogenaamde Forms 20-F die ondernemingen moeten deponeren in de Verenigde Staten vanwege een beursnotering aldaar. Als de desbetreffende ondernemingen verslaggevingsregels toepassen die afwijken van de Amerikaanse generally accepted accounting principles (US GAAP) dan moeten zij de invloed daarvan op het nettoresultaat en het eigen vermogen kwantificeren. Deze informatie geeft inzicht in de effecten op de gepresenteerde cijfers van de toepassing van IASs, althans voor zover die overeenstemmen met US GAAP.

Voor de goede orde zij vermeld dat bij de berekening van de invloed veelal is uitgegaan van brutobedragen, dat wil zeggen dat mogelijke belastingeffecten daarin niet zijn verdisconteerd. In de Forms 20-F worden vaak alleen de brutobedragen van de aanpassingen aan US GAAP vermeld. Het zal duidelijk zijn dat de belastingeffecten de invloed op het nettoresultaat en het eigen vermogen belangrijk kunnen mitigeren.

4 In VNO-NCW (1998) worden soortgelijke categorieën onderscheiden.

5 Dit verschil wordt door VNO-NCW (1998) ten onrechte geclassificeerd als 'IASC-regelgeving die bestaande opties in de Nederlandse wet- en regelgeving inperkt'. Het verschil moet mijns inziens worden opgenomen in de categorie 'IASC-regelgeving die in strijd is met Nederlandse wettelijke bepalingen', omdat het buiten de consolidatie houden van groepsmaatschappijen met sterk afwijkende bedrijfsactiviteiten in Nederland niet een vrije keuze is maar - in voorkomende gevallen - een verplichting.

6 Zie Vergoossen en Polman (1995) voor een bespreking van de aanpassingen die Nederlandse ondernemingen met een 
beursnotering in de Verenigde Staten naar aanleiding van de afwijkende behandeling van de betaalde goodwill in de periode 1984-1993 in hun Forms 20-F hebben moeten opnemen.

7 De verschillen tussen IASs en de Nederlandse wet- en regelgeving met betrekking tot voorzieningen heb ik geclassificeerd als 'IASC-regelgeving die bestaande opties in de Nederlandse wet- en regelgeving inperkt'. Dit is in overeenstemming met de classificatie van VNO-NCW (1998). Artikel 2:374.1 BW luidt als volgt: 'Op de balans worden voorzieningen opgenomen tegen: (a) verplichtingen en verliezen waarvan de omvang op de balansdatum onzeker is, doch rederlijkerwijs is te schatten; (b) op de balansdatum bestaande risico's ter zake van bepaalde te verwachten verplichtingen of verliezen waarvan de omvang redelijkerwijs is te schatten; (c) kosten welke in een volgend boekjaar zullen worden gemaakt, mits het maken van die kosten zijn oorsprong mede vindt in het boekjaar of in een voorafgaand boekjaar en de voorziening strekt tot gelijkmatige verdeling van lasten over een aantal boekjaren.' Als deze wetsbepaling zo wordt geïnterpreteerd dat het opnemen van de daarin getypeerde voorzieningen een verplichtend karakter heeft, zou dit betekenen dat IAS 37 op een aantal punten strijdig is met de Nederlandse wet. Desalniettemin heb ik er niet voor gekozen om de verschillen tussen IASs en de Nederlandse wet- en regelgeving met betrekking tot voorzieningen te classificeren als 'IASC-regelgeving die in strijd is met Nederlandse wettelijke bepalingen', omdat in Nederland de nodige fiexibiliteit bestaat ten aanzien van de interpretatie c.q. invulling van de criteria die gelden bij het bepalen van het moment waarop het opnemen van een voorziening verplicht wordt, dat wil zeggen er is een groot grijs gebied waarin het vormen van voorzieningen in Nederland min of meer optioneel is. IAS 37 verkleint dit gebied aanmerkelijk.

8 Zie Overboom en Vergoossen (1997) voor een onderzoek naar het voorzieningenbeleid van Nederlandse ondernemingen.

9 Uit onderzoek van Vergoossen (1996) blijkt dat bij Nederlandse ondernemingen met een beursnotering in de Verenigde Staten over het algemeen een jaarrekeningbeleid valt te onderkennen in de richting van het steeds meer toepassen van grondslagen die overeenstemmen met US GAAP.

10 Zie bijvoorbeeld Arnold en Van der Voorn (1995) die hebben onderzocht in hoeverre een 26 -tal beursgenoteerde Nederlandse ondernemingen verslaggevingsgrondslagen toepassen die overeenstemmen met IASs. Het blijkt dat tussen de in het onderzoek betrokken ondernemingen grote verschillen bestaan.

11 Zie ook Van der Tas (1996) die een onderscheid maakt tussen permanente, semi-permanente en tijdelijke verschillen. 